\title{
IN VITRO ASSESSMENT OF BINDING CAPACITY OF COMBINED ADSORBENT (BENTONITE WITH YEAST CELL WALL EXTRACTS) AND AFLATOXIN B1
}

\author{
Ksenija Nešić ${ }^{1 *}$, Sandra Jakšić ${ }^{2}$, Nenad Popov², \\ Milica Živkov-Baloš², Marko Pajić ${ }^{2}$ Bojan Zloh ${ }^{3}$, Vladimir Polaček ${ }^{2}$ \\ ${ }^{1}$ Institute of Veterinary Medicine of Serbia, Belgrade, Republic of Serbia \\ ${ }^{2}$ Scientific Veterinary Institute „Novi Sad“, Novi Sad, Republic of Serbia \\ ${ }^{3}$ INBERG d.o.o., Boljevci, Republic of Serbia
}

\section{Abstract}

The contamination of animal feed with mycotoxins is a worldwide problem in the animal husbandry, but it also represents a serious threat for the whole food chain. The health of both animals and humans is potentially endangered. From this point of view aflatoxins are a class of mycotoxins especially well known. Therefore, new strategies to combat these natural contaminants are constantly being developed. The most applied method to protect animals against aflatoxicosis is the utilization of feed additives aimed to adsorb aflatoxins. In order to estimate adsorbing potential of feed additive "MycoStop DUPLO", designed for the prevention and/or alleviation of adverse effects of aflatoxin $B_{1}$ in animal nutrition, in vitro trial was conducted. As a result of the experiment, conducted at $\mathrm{pH} 5$ during 120 minutes of incubation at $37^{\circ} \mathrm{C}$, the optimal formulation of the adsorbent was revealed. This product, in low concentration and in the presence of high amounts of toxin, met the stringent European regulation requirements for minimum $90 \%$ aflatoxin binding efficiency $(90.1 \%$ achieved with $0.02 \%$ adsorbent and $4 \mathrm{mg} / \mathrm{L}$ toxin concentration). In higher adsorbent $(0.2 \%)$, and lower toxin $(0.2 \mathrm{mg} / \mathrm{L})$ conditions, adsorption was $99.6 \%$. Such outcome indicated the validity of in vitro experimental approach which can serve as a reliable fast tool for triage of adsorbents and preselect them for in vivo tests.

Key words: feed, feed additives, mycotoxins

\footnotetext{
${ }^{1 \star}$ Corresponding author: ksenija.nesic@gmail.com
} 


\title{
IN VITRO PROCENA KAPACITETA VEZIVANJA KOMBINOVANOG ADSORBENTA (BENTONIT I EKSTRAKT ĆELIJSKOG ZIDA KVASCA) I AFLATOKSINA B
}

\author{
Ksenija Nešić ${ }^{1}$, Sandra Jakšić ${ }^{2}$ Nenad Popov², \\ Milica Živkov-Baloš², Marko Pajić2 ${ }^{2}$ Bojan Zloh ${ }^{3}$, Vladimir Polaček ${ }^{2}$ \\ ${ }^{1}$ Naučni institut za veterinarstvo Srbije, Beograd, Republika Srbija \\ ${ }^{2}$ Naučni institut za veterinarstvo "Novi Sad”, Novi Sad, Republika Srbija \\ ${ }^{3}$ INBERG d.o.o., Boljevci, Republika Srbija
}

\section{Kratak sadržaj}

Kontaminacija hrane za životinje mikotoksinima predstavlja svetski problem u stočarstvu, ali i ozbiljnu pretnju u čitavom lancu hrane. Potencijalno je ugroženo zdravlje i životinja i ljudi, a sa ovog aspekta aflatoksini su naročito značajna klasa mikotoksina. Stoga se neprestano razvijaju nove strategije za borbu protiv ovih prirodnih hazarda. Najčešći vid zaštite životinja od aflatoksikoze jeste korišćenje dodataka u hrani za životinje koji adsorbuju aflatoksine. $\mathrm{U}$ cilju procene kapaciteta adsorpcije aditiva „MycoStop DUPLO“, namenjenog prevenciji i/ili ublažavanju štetnih efekata aflatoksina $\mathrm{B}_{1} \mathrm{u}$ ishrani životinja, sprovedeno je in vitro ispitivanje. Kao rezultat eksperimenta izvedenog na $\mathrm{pH} 5$ tokom 120 minuta inkubacije na $37^{\circ} \mathrm{C}$, otkrivena je optimalna formulacija adsorbenta, koji je u niskoj koncentraciji i u prisustvu velike količine toksina ispunio stroge zahteve evropskih propisa za minimalnom efikasnošću vezivanja aflatoksina od $90 \%$ (90,1\% ostvareno sa $0,02 \%$ adsorbenta i $4 \mathrm{mg} / \mathrm{L}$ toksina). U uslovima veće količine adsorbenta $(0,2 \%)$ i manje toksina $(0,2 \mathrm{mg} / \mathrm{L})$ vezalo se $99,6 \%$. Takav ishod ukazuje na validnost in vitro eksperimentalnog pristupa koji može da posluži kao pouzdan brzi alat za trijažu adsorbenasa i njihovu predselekciju za in vivo testove.

Ključne reči: hrana za životinje, dodaci hrani za životinje, mikotoksini 


\section{INTRODUCTION}

Mycotoxins contaminate food chain through food and feed crops, mainly cereals, which become infested prior to and during harvest, or during (improper) storage. They are produced as secondary metabolites of different types of fungus under the favourable environmental conditions, when temperature and moisture are appropriate. Climate changes during the last decade in particular contributed to the escalation of this problem (Nešić et al., 2014; Nešić, 2018; Jakšić et al., 2017, 2018, 2019). Aflatoxins are strong (Class I, IARC, 2002) carcinogens in mammalian species, difuranocoumarin derivatives produced by different species of Aspergillus (Aspergillus flavus, Aspergillus parasiticus, Aspergillus nomius and Aspergillus pseudotamarii). Several types of aflatoxin (14 or more) are found in nature, and $B_{1}, B_{2}, G_{1}, G 2$ and $M_{1}$ are of major importance. Aflatoxins $B_{1}, B_{2}, G_{1}$ and $G 2$ are direct secondary metabolites of fungi, whereas aflatoxin $M 1$ is produced by metabolizing aflatoxin $B_{1}\left(A_{F} B_{1}\right)$, which is usually a major product of toxigenic strains (WHO, 2018). The presence of mycotoxin in feed results in huge economic losses for animal breeders caused by decreased performance and production, increased susceptibility to diseases and other adverse effects (Rawal et al., 2010).

Since the mycotoxins have an important impact, there is a continuous effort to develop various ways to alleviate and/or prevent their harmfulness. The approach by using different feed additives, which either adsorb mycotoxins on their surface or foment enzyme degradation of mycotoxins proved to be particularly effective (EFSA, 2009; Nedeljkovic-Trailovic et al., 2015). The output depends mostly on the chemical structure of the adsorbent, as well as on the type of present mycotoxin. Mineral adsorbents (e.g. hydrated sodium calcium aluminosilicate, sodium bentonit, dietary clay and zeolites) and active charcol are among the most used for this purpose. These are the substances that are not resorbable from the gut and that physically bind target chemicals and consequently block their resorption (Nešić et al., 2014). The feasibility of utilizing organic adsorbents has also been examined, particularly those isolated from the yeast cell wall that possess significant adsorption capacity (Devegowda et al., 2004; Nešić et al., 2008). Recently, some new types of additives which contain microorganisms have been developed. They have the ability to enzymatically modify the mycotoxin structure (Fuchs et al. 2002; Nešić et al. 2011, 2012).

The ability of different adsorbents to ameliorate aflatoxin $\mathrm{B}_{1}$ toxicity was tested in in vitro and in vivo conditions and the findings mostly correlated (Vekiru et al., 2015). Supplementation of diets with selected adsorbents, especially of the bentonite type, seems to almost fully protect animals against 
aflatoxicosis, so the EFSA Scientific Report gives an actual and comprehensive overview on this topic (EFSA, 2009). Bentonites are composed predominantly of smectite. However, a wide variety of other minerals may occur as impurities. The dioctahedral smectite mineral montmorillonite is present in most bentonites. Depending on the dominant exchangeable cations, bentonite may be referred to as calcium or sodium bentonite. Sodium bentonite swells and expands to a greater degree than its calcium equivalent. Calcium bentonite may be converted to sodium bentonite, then termed sodium activated bentonite. The type of the cation on the surface of the aluminium sheet ( $\mathrm{Ca}$ or $\mathrm{Na}$ ) may affect the binding capacity of the montmorillonite (EFSA, 2011).

Besides its excellent nutritional value, yeasts and yeast cell wall can also be used as adsorbents for mycotoxins. The adsorption of mycotoxins can be enhanced by using yeast cell walls instead of whole cells. The cell walls harbouring polysaccharides (glucan, mannan), proteins and lipids exhibit numerous different and easily accessible adsorption centers including different adsorption mechanisms, e.g. hydrogen bonding, ionic, or hydrophobic interaction (Huwig et al., 2001). Regarding polysaccharides, including $\beta$-D-glucan and $\alpha$-mannan, it has been proposed that their antigenotoxic action mechanism is related to their action as antioxidant agents (Pereyra et al., 2012). The ability of $\beta$-D-glucan to partially prevent DNA damage induced by $\mathrm{AFB}_{1}$ in mouse hepatocytes was determined in a trial (Madrigal-Bujaidar, 2015). The data suggested the formation of a supramolecular complex between $\mathrm{AFB}_{1}$ and $\beta-\mathrm{D}$ glucan. Mannan oligosaccharide is a potent immunomodulator which alleviates the damages of $\mathrm{AFB}_{1}$ (Sun et al., 2019).

The aim of the presented in vitro trial was to estimate adsorbing potential of "MycoStop DUPLO". It is a feed additive which combines bentonite and yeast components and is intended for prevention and/or alleviation of adverse effects of aflatoxin $B_{1}$ in animal nutrition.

\section{MATERIAL AND METHODS}

\section{Chemicals and mycotoxin adsorbents}

$\mathrm{AFB}_{1}$ standard was purchased from Sigma-Aldrich, Cat No A6636 ((St. Louis, MO, USA). Stock solution of $\mathrm{AFB}_{1}$ was prepared by dissolving the toxin in acetonitrile $(10 \mu \mathrm{g} / \mathrm{mL})$. Acetonitrile HPLC gradient grade was purchased from Fisher Scientific (Leicestershire, UK). To perform the adsorption experiments, appropriate volume of stock standard solution was evaporated to dryness and dissolved in buffer solution. Acetate buffer (pH5), $0.1 \mathrm{~mol} / \mathrm{L}$ was prepared by dissolving $0.82 \mathrm{~g}$ of sodium acetate $\left(\mathrm{C}_{2} \mathrm{H}_{3} \mathrm{NaO}_{2}\right.$; Lach-Ner, Nera- 
tovice, Czech Republic) in approximately $90 \mathrm{~mL}$ of distilled water. Then, the solution was adjusted to $\mathrm{pH} 5$ with acetic acid analytical grade $\left(\mathrm{C}_{2} \mathrm{H}_{4} \mathrm{O}_{2}\right)$, and filled up to $100 \mathrm{~mL}$ with distilled water.

Five samples of different adsorbents ( 1 - 5) were provided by INBERG d.o.o. (Belgrade, Republic of Serbia). Four of them (2 - 5) consisted of bentonite (smectite - dioctahedral montmorillonite) and yeast cell wall extracts, in different combination, while one (labelled 1) contained zeolite as inorganic component.

\section{Physico-chemical characterization tests}

The physico-chemical properties of adsorbents were examined as moisture content, acidity and swell index. Moisture content in adsorbents was determined by drying in oven (Memmert UNB 500, Germany) at $105^{\circ} \mathrm{C}$ to constant mass. The acidity of the adsorbent samples was measured in 1:10 adsorbent: water suspension (De Mil et al., 2015). The suspensions were shaken for $2 \mathrm{~h}$ and were left to sediment for next $2 \mathrm{~h}$ under closed lid. The $\mathrm{pH}$ of the supernatant was measured using $\mathrm{pH}$ meter (Consort, Turnhout, Belgium). For determination of the swell index, the ASTMD5890, 2011 method was used.

\section{In vitro experiment design}

The assessment of aflatoxin $\mathrm{B}_{1}$ adsorption capacity was accomplished in accordance with the Regulation (EU) No 1060/2013 (European Commission, 2013), an approved method for the evaluation of bentonites authorized as feed additives against $\mathrm{AFB}_{1}$. The test was carried out in a buffer solution at $\mathrm{pH}$ 5.0, at $37^{\circ} \mathrm{C}$, for 120 minutes, with a concentration of $4 \mathrm{mg} / \mathrm{L}$ for $\mathrm{AFB}_{1}$ and $0.02 \%$ $(w / v)$ for the adsorbent (phase I). The best performing adsorbents from the phase I were examined in the second phase of the experiment. In this phase, II binding capacity was investigated using a standard solution of $0.2 \mathrm{mg} / \mathrm{L} \mathrm{AFB}_{1}$ and the adsorbent in the concentration of $0.2 \%(w / v$; Prapapanpong et al., 2019). All the tests were done in triplicate.

After incubation (shaking for $2 \mathrm{~h}$ at $37^{\circ} \mathrm{C}$ ), samples were filtered (syringe filters $0.22 \mu \mathrm{m}$; LLG-Labware, Meckenheim, Germany) and the solution was analyzed by an HPLC Dionex UltiMate 3000 Series system equipped with a FLD 3100 detector (Thermo Scientific, Germering, Germany) at $30^{\circ} \mathrm{C}$, and $\lambda_{\text {ex }} 365 \mathrm{~nm}, \lambda_{\text {em }} 435 \mathrm{~nm}$. The HPLC column was Supelcosil ${ }^{\mathrm{TM}}$ LC-18-DB, 250 x $4.6 \mathrm{~mm}$ (particle size $5 \mu \mathrm{m}$; Merck, Darmstadt, Germany), fitted with a guard column. The mobile phase was acetonitrile: water (50:50, $v / v)$ filtered through $0.22 \mu \mathrm{m}$ membrane filter, at a flow rate of $1.2 \mathrm{~mL} / \mathrm{min}$. The system was controlled by Chromeleon ${ }^{\odot} 7$ software (Thermo Scientific, Germering, 
Germany). The peak areas at aflatoxin $\mathrm{B}_{1}$ retention times were compared to the corresponding calibration curves. Calculation of $\mathrm{AFB}_{1}$ adsorption rates (\%) was performed according to the following equation:

$\mathrm{BC}_{\mathrm{AFB} 1}=\left(1-\mathrm{C}_{\mathrm{I}} / \mathrm{C}_{0}\right) \times 100 \%$

$\mathrm{BC}_{\mathrm{AFB} 1}=$ binding capacity; $\mathrm{C}_{\mathrm{I}}=$ concentration of free $\mathrm{AFB}_{1}$ after the incubation period; $\mathrm{C}_{0}=$ initial fortified concentration of the $\mathrm{AFB}_{1}$.

\section{RESULTS}

The results of physico-chemical characterization tests showed different properties of adsorbents regarding moisture content, swell index and acidity (Table 1).

Table 1. Results of physico-chemical characterization tests

\begin{tabular}{cccc}
\hline $\begin{array}{c}\text { Sample } \\
\text { label }\end{array}$ & Moisture content (\%) & $\begin{array}{c}\text { Swell index } \\
(\mathbf{m L} / \mathbf{2 g})\end{array}$ & $\mathbf{p H}$ \\
\hline $\mathbf{1}$ & $4.80 \pm 0.18$ & 2 & $6.4 \pm 0.1$ \\
\hline $\mathbf{2}$ & $10.46 \pm 0.18$ & 8 & $6.5 \pm 0.4$ \\
\hline $\mathbf{3}$ & $9.80 \pm 0.15$ & 13 & $7.6 \pm 0.1$ \\
\hline $\mathbf{4}$ & $7.73 \pm 0.03$ & 5 & $6.5 \pm 0.1$ \\
\hline $\mathbf{5}$ & $7.22 \pm 0.11$ & 4 & $7.4 \pm 0.2$ \\
\hline
\end{tabular}

Test results for the adsorption of aflatoxin $\mathrm{B}_{1}(4 \mathrm{mg} / \mathrm{l})$ by different adsorbents $1-5(0.02 \% \mathrm{w} / \mathrm{v})$ at $\mathrm{pH} 5$ after 120 minutes (phase I) were from $9.1 \pm$ $1.9 \%$ to $90.1 \pm 0.2 \%$. In the second phase (phase II) of the trial, which was performed with high adsorbent $(0.2 \% \mathrm{w} / \mathrm{v})$ and low toxin concentration $(0.2$ $\mathrm{mg} / \mathrm{L}$ ), the best performance was confirmed for the sample number 4 as binding capacity was $99.6 \pm 0.03 \%$ (Table 2 ).

Table 2. Binding results for different adsorbents $(1-5)$ and aflatoxin $\mathrm{B}_{1}$ in the phase I and II (pH5, 37 $\left.{ }^{\circ} \mathrm{C}, 120 \mathrm{~min}\right)[\%]$

\begin{tabular}{ccc}
\hline $\begin{array}{c}\text { Sample } \\
\text { label }\end{array}$ & $\begin{array}{c}\text { Phase I: } \text { AFB }_{1} \mathbf{4} \mathbf{~ m g} / \mathbf{l}+ \\
\text { adsorbent } \mathbf{0 . 0 2} \% \mathbf{w} / \mathbf{v}\end{array}$ & $\begin{array}{c}\text { Phase II: AFB } \mathbf{0 . 2} \mathbf{~ m g} / \mathbf{L} \\
\text { +adsorbent } \mathbf{0 . 2} \% \mathbf{w} / \mathbf{v}\end{array}$ \\
\hline $\mathbf{1}$ & $9.1 \pm 1.9$ & $/$ \\
\hline $\mathbf{2}$ & $88.3 \pm 1.3$ & $97.2 \pm 0.3$ \\
\hline $\mathbf{3}$ & $85.7 \pm 0.8$ & $93.8 \pm 2.4$ \\
\hline $\mathbf{4}$ & $90.1 \pm 0.2$ & $99.6 \pm 0.03$ \\
\hline $\mathbf{5}$ & $27.0 \pm 0.5$ & $/$ \\
\hline
\end{tabular}


The characterization study showed that all samples differed in physicochemical properties, such as moisture content and swelling index. Besides that, their ability to adsorb aflatoxin $\mathrm{B}_{1}$ also varied greatly.

\section{DISCUSSION}

The variable properties of adsorbents are the result of their different composition in terms of the ratio of organic and inorganic components. Sample number 1 mostly differed, as it contained zeolite for mineral component instead of montmorillonite. However, more samples need to be investigated for correlation assessment between physico-chemical properties of adsorbents and the amounts of adsorbed toxin.

According to Regulation (EU) No 1060/2013 (European Commission, 2013), $\mathrm{AFB}_{1}$ good binding capacity $\left(\mathrm{BC}_{\mathrm{AFB}}\right)$ should be above $90 \%$, which was achieved with the product number 4 . The adsorbent was tested under ,intensified conditions" (low binder concentration and high toxin concentration), as described by Vekiru et al. (2015) and such concept was carried out to get closer to the limit of the product's adsorption capacities. In the Phase II, an extremely high percentage of binding for the same sample confirmed the previous good outcome.

Based on the obtained results, the material labelled with number 4 was categorized as good and its composition proved to be the best of all the examined samples. Bentonite, which is the main component of this product, is well known for its ability to bind aflatoxins (EFSA, 2009, 2011), while natural yeast extracts, a cell wall derivatives of Saccharomyces cerevisiae, show considerable binding ability with several commonly occurring mycotoxins (Devegowda and Murthy, 2005) and are beneficial in minimizing their adverse effects in animals (Nešić et al., 2008). Such multilevel mechanism of action, achieved through the complex composition of this adsorbent, indicate various usage potentials and also enable further efficiency testing of this feed additive.

The poorest performing of the zeolite sample was sample (No 1), which is in accordance with the results of Thieu and Pettersson (2008) who reported that bentonite has a better ability to adsorb AFB1 than zeolite. According to Marroquín-Cardona et al. (2009), this could be due to the smaller size of the zeolite pores ( 4 - $7 \AA$ in case of natural clinoptilolite) in comparison with AFB1 size (10.4 - $12.8 \AA$ ), which limits the adsorption to the external surface only.

As reported in the case of charcoal, in vitro success is not always a sufficient criterion to choose an adsorbent for practical use, so in vivo trials should verify its usefulness (Diaz et al., 2002; 2004). Even among good binders, there were 
differences in in vivo efficacy, indicating that in vitro testing alone is not always adequate for complete evaluation of the additive (Vekiru et al., 2015). Nevertheless, the advantage of in vitro test is the possibility of rapid screening efficiency of a large number of adsorbents. In this way, the reduction of mycotoxin toxicity is also indirectly confirmed. Thus, in vitro experimental approach can serve as a reliable fast tool for triage of adsorbents. Vekiru et al. (2015) showed in their trial that it is a helpful to preselect an $\mathrm{AFB}_{1}$ adsorbent and to predict the in vivo $\mathrm{AFB}_{1}$ detoxifying performance.

\section{CONCLUSION}

As a result of the presented experiment, the optimal formulation of the adsorbent No 4 "MycoStop DUPLO" was found, which at low concentration and in the presence of high amounts of toxin met the stringent European regulation requirements for the minimum $90 \%$ aflatoxin binding efficiency. Based on good in vitro aflatoxin $\mathrm{B}_{1}$ adsorption results, it seems pertinent to extend in vivo studies of the selected adsorbent. As, according to literature data, it combines bentonite and yeast polysaccharides, it is reasonable to perform assays with other mycotoxins in the future and expect promising results.

Although there is a regulation on the in vitro testing of bentonite in the EU, many national regulations worldwide do not cover estimation of binding capacity of adsorbents used as additives in animal feed. Also, there is no unique methodology for analyzing adsorbents and variously designed experiments could be found in the literature. Therefore, the information on the adsorption capacity is obtained in different ways and is not always comparable. It would be necessary to standardize this procedure and establish regulations to cover this significant area.

\section{ACKNOWLEDGEMENT}

This paper is published as part of the project financed by the Inovation Fund of the Republic of Serbia. The authors cordially thank INBERG d.o.o., Belgrade, Serbia for providing tested adsorbents.

\section{Author's contributions:}

$\mathrm{KN}$-conducted the experiment and paper concept and writing, SJ- concept and design of the study, NP- experiment performance, MZB-experiment concept and revising the manuscript critically, MP- providing material and data 
collection, BZ-initial idea and providing material, VP-experiment organization and material provision.

\section{Competing Interests}

The authors declare that they have no competing interests.

\section{REFERENCES}

1. ASTM D5890 Bentonite swell index, Technical note, Global Syntetics.

2. De Mil T., Devreese M., De Baere S., Van Ranst E., Eeckhout M., De Bacjer P., Croubels S. 2015. Characterization of 27 Mycotoxin Binders and the Relation with in Vitro Zearalenone Adsorption at a Single concentration. Toxins, 7, 21-33. doi: 10.3390/toxins7010021.

3. Devegowda G., Reddy N.B., Shashidhara R.G. 2004. Ability of modified glucomannan to sequestrate T-2 toxin in the gastrointestinal tract of chicken. Asian Australian Journal of Animal Science, 17, 2, 259. doi: 10.5713/ ajas.2004.259.

4. Devegowda G. and Murthy T.N.K. 2005. Mycotoxins: Their adverse effects in poultry and some practical solutions. In: The Mycotoxin Blue Book. Ed. D. E. Diaz, Nottingham University Press, Nottingham, UK, 25-56.

5. Diaz D.E., Hagler W.M., Hopkins B.A., Whitlow, L.W. 2002. Aflatoxin binders I: in vitro binding assay for aflatoxin B1 by several potential sequestering agents. Mycopathologia, 156, 223-226. doi: 10.1023/a:1023388321713.

6. Diaz D.E., Hagler W.M., Blackwelder J.T., Eve J.A., Hopkins B.A., Anderson K.L., Jones F.T., Whitlow, L.W. 2004. Aflatoxin binders II: Reduction of aflatoxin $\mathrm{M} 1$ in milk by sequestering agents of cows consuming aflatoxin in feed. Mycopathologia, 157, 233-241. doi:10.1023/ B:MYCO.0000020587.93872.59.

7. European Commission (EC). 2013. Commission Implementing Regulation (EU) No 1060/2013 of 29 October 2013 concerning the authorisation of bentonite as a feed additive for all animal species, Official Journal of the European Union, L 289: 33-37.

8. European Food Safety Authority (EFSA). 2009. Review of mycotoxin-detoxifying agents used as feed additives: mode of action, efficacy and feed/ food safety. EFSA-Q-2009-00839. http://www.efsa.europa.eu/en/scdocs/ doc/22e.pdf

9. European Food Safety Authority (EFSA). 2011. Panel on Additives and Products or Substances used in Animal Feed (FEEDAP); Scientific Opinion 
on the safety and efficacy of bentonite (dioctahedral montmorillonite) as feed additive for all species. EFSA Journal, 9, 2, 24.

10. Fuchs E., Binder E.M., Heidler D., Krska R. 2002. Structural characterization of metabolites after the microbial degradation of type A trichothecens by the bacterial strain BBSH 797. Food Additives and Contaminants, 19, 4, 379-386. doi: 10.1080/02652030110091154.

11. Huwig A., Freimund S., Kappeli O., Dutler H. 2001. Mycotoxin detoxication of animal feed by different adsorbents. Toxicology Letters 122, $179-$ 188. doi: 10.1016/s0378-4274(01)00360-5.

12. IARC - International Agency for Research on Cancer. 2002. IARC Monograph on the Evaluation of Carcinogenic Risk to Humans. 82, 171.

13. Jakšić S., Živkov-Baloš M., Prodanov-Radulović J., Jajić I., Krstović S., Stojanov I., Mašić Z. 2017. Aflatoxin M1 in milk and assessing the possibility of its occurrence in milk products. Archives of Veterinary Medicine, 10, 1, 37- 50. doi:10.46784/e-avm.v10i1.80.

14. Jakšić S., Popov N., Živkov Baloš M., Prodanov-Radulović J., Abramović B. 2018. Fumonisins in pig feed. Arhiv veterinarske medicine, 11, 2, 43 - 51. doi:10.46784/e-avm.v11i2.25.

15. Jakšić S., Zivkov Balošs M., Jajic I., Abramović B. 2019. Fumonisins in Serbian Corn: Long-time Assessment under Actual Climate Change Conditions. Cereal Research Communications, 47, 4, 714-723. doi: 10.1556/0806.47.2019.45.

16. Madrigal-Bujaidar E., Morales-González J.A., Sánchez-Gutiérrez M., Izquierdo-Vega J.A., Reyes-Arellano A., Álvarez-González I., Pérez-Pasten R., Madrigal-Santillán E. 2015. Prevention of Aflatoxin B1 Induced DNA Breaks by $\beta$-D-Glucan. Toxins, 7, 2145-2158. doi: 10.3390/toxins7062145.

17. Marroquín-Cardona A., Deng Y., Taylor J.F., Hallmark C.T., Johnson N.M., Phillips T.D. 2009. In vitro and in vivo characterization of mycotoxin-binding additives used for animal feeds in Mexico. Food Additives and Contaminants, 26, Part A, 733-743. doi: 10.1080/02652030802641872.

18. Nedeljkovic-Trailovic J., Trailovic S., Resanovic R., Milicevic D., Jovanovic M., Vasiljevic M. 2015. Comparative Investigation of the Efficacy of Three Different Adsorbents against OTA-Induced Toxicity in Broiler Chickens. Toxins, 7, 1174-1191. doi: 10.3390/toxins7041174.

19. Nešić K., Resanovic R., Nešić V., Sinovec Z. 2008. Efficacy of mineral and organic adsorbent in alleviating harmful effects of zearalenone on pigs performance and health. Acta Veterinaria Beograd, 58, 2-3, 211-219. doi: 10.2298/AVB0803211N. 
20. Nešić K., Resanovic R., Jakic-Dimic D., Nešić V. 2011. Efficiency of various feed additives on the performance of broilers treated with T-2 toxin. Biotechnology in Animal Husbandry 2-3, 2, 705-711. doi: 10.2298/ BAH $1103705 \mathrm{~N}$.

21. Nešić V., Resanovic R., Marinkovic D., Nešić K., Lazarevic M., Nešić S., Aleksic-Kovacevic S. 2012. Efficacy of T-2 toxin detoxifying agent in broiler chickens. Acta Veterinaria Beograd, 62, 2-3, 171-182. doi: 10.2298/ AVB1203171N.

22. Nešić K., Ivanovic S., Nešić V. 2014. Fusarial Toxins - Secondary Metabolites of Fusarium Fungi. Reviews of Environmental Contamination and Toxicology, 228, 101-120. doi: 10.1007/978-3-319-01619-1_5.

23. Nešić K. 2018. Mycotoxins - climate impact and steps to prevention based on prediction. Acta Veterinaria-Beograd, 68, 1, 1-15. doi: 10.2478/acve2018-0001.

24. Pereyra C.M., Cavaglieri L.R., Chiacciera S.M., Dalcero A. 2012. The corn influence on the adsorption levels of aflatoxin $\mathrm{B} 1$, and zearalenone by yeast cell wall. Journal of Applied Microbiology, 114, 655-662. doi: 10.1111/ jam.12082.

25. Prapapanpong J. , Udomkusonsri P. , Mahavorasirikul W. , Choochuay S., Tansakul N. 2019. In vitro studies on gastrointestinal monogastric and avian models to evaluate the binding efficacy of mycotoxin adsorbents by liquid chromatography-tandem mass spectrometry. Journal of Advanced Veterinary and Animal Research, 6, 1, 125-132. doi: 10.5455/javar.2019. f322.

26. Rawal S., Kim J.E., Coulombe Jr., R. 2010. Aflatoxin B1 in poultry: toxicology, metabolism and prevention. Research in Veterinary Science, 89, 325-331. doi: 10.1016/j.rvsc.2010.04.011.

27. Sun Y., Su J., Yang S., Liu Z., Liu D, Gan F., Chen X., Huang K. 2019. Mannan Oligosaccharide Protects against the Aflatoxin-B1-Promoted Influenza Replication and Tissue Damages in a Toll-Like-Receptor-4-Dependent Manner. Journal of Agricultural and Food Chemistry. 16, 67, 2, 735-745. doi: 10.1021/acs.jafc.8b05829.

28. Thieu N.Q. and Pettersson H. 2008. In vitro evaluation of the capacity of zeolite and bentonite to adsorb aflatoxin $\mathrm{B} 1$ in simulated gastrointestinal fluids. Mycotoxin Research, 24, 124-129. doi: 10.1007/BF03032338.

29. Vekiru E., Fruhauf S., Rodrigues I., Ottner F., Krska R., Schatzmayr G., Ledoux D.R., Rottinghaus G.E., Bermudez A.J. 2015. In vitro binding assessment and in vivo efficacy of several adsorbents against aflatoxin B1. World Mycotoxin Journal, 8, 4, 477-488. doi:10.3920/WMJ2014.1800. 
Arhiv veterinarske medicine, Vol. 13, No. 1, 41 - 52, 2020

Nešić, K. ... et al.: In vitro assessment of binding...

30. WHO 2018. Available at: https://www.who.int/foodsafety/FSDigest_Aflatoxins_EN.pdf. Accessed 6.2.2020.

Received: 03.03.2020.

Accepted: 17.05.2020. 